\title{
European Cities in Competition and the New 'Uses' of Urban Design
}

\section{ASPA GOSPODINI}

\begin{abstract}
Throughout the history of urban forms, major urban design schemes and avant-garde design of space have been mostly an outcome of economic growth of cities and countries. Marking the era of globalization, a reverse procedure has taken place in the last decade or so; urban design appears to be consciously 'used' as a means of economic development of cities in the new competitive milieu. This paper seeks to investigate the new role of urban design in the framework of contemporary development of European cities, in relation to their development potentials and constraints within the European urban system as a whole. It attempts to examine the potential of urban design for different classes and groups of European cities: metropolitan cities, larger cities and smaller cities, as well as cities in the core and cities in the periphery of Europe (geographical and/or economic). It is argued that urban design is an emerging new factor affecting development prospects in all classes and groups of European cities, while it becomes particularly crucial for two classes of cities, representing the opposite extremes of the European urban system: metropolitan cities and smaller peripheral cities without indigenous resources for development.
\end{abstract}

\section{European Cities Functioning as a 'Global Urban System'}

In the last decade, a growing number of studies with different scientific concerns appear to converge in that the dynamics of urban networks have been strongly affected by late 20th-century economic globalization (see, for instance, Castells, 1989; King., 1990; Sachar, 1990; Sassen, 1994; Amin \& Thrift, 1995; Savitch, 1996; Hall, 1998; Short \& Kim, 1999). More than ever, markets appear to transcend the borders and interests of nation states while the ability of individual countries to direct their internal economies and shape the manner in which they interact with external structures has declined accordingly. These changes reshape urban networks and rearrange the distribution of opportunities and income in cities, regardless of the cities' degree of participation in the global economy. As Shaw (2001) states, all cities in almost every nation have been affected to a greater or lesser degree. Changes involve urban networks as well as the organization of space within individual cities (Sassen, 2001; Shaw, 2001).

In Europe, the process of economic globalization, along with the process of integration within the European Union in the last decade, ${ }^{1}$ has altered the function of the European urban system. European cities are increasingly linked 
to forces external to their national boundaries and they appear to function as unified networks of urban settlements (Commission of the European Communities (CEC), 1992). Castells (1993) believes that the more national states of Europe fade in their role, the more cities will emerge as a driving force in the making of new European society. Other scholars go as far as to argue that "Europe is becoming a community of cities rather than a community of nations or/and countries" (Simioforidis, 1998, p. 144).

In this global urban system, European cities do not structure a single and/or strict hierarchy but, rather, form overlapping and flexible hierarchies according to their particular performance in different sectors and activities (e.g. manufacturing, services, high technology and tourism, etc.) as well as spheres of influence-regional, national and international (CEC, 1992; Grasland \& JensenButler, 1997; Petrakos \& Economou, 1999). In this framework, the key process is an increasing competition among cities to upgrade their status in the hierarchies of the global urban system; ${ }^{2}$ or, in other words, an inter-city competition for a new centrality (CEC, 1992; Brotchie et al., 1995; Cox, 1995; Duffy, 1995; JensenButler et al., 1997; Simioforidis, 1998). ${ }^{3}$ Some evidence as to the phenomenon that European cities are functioning as a global urban system, in which there is increasing competition among cities to upgrade their status, are the numerous networks of cities (Grasland \& Jensen-Butler, 1997) that have been organized to promote co-operation in exchanging policies and best practices as well as in developing joint ventures in a variety of economic activities and social problems (new technologies, tourism, urban transport, social housing, environmental pollution, unemployment, criminality and social segregation, etc.).

\section{The Potential of Urban Design as a Means of Economic Development of Cities}

In the framework of inter-city competition, urban design appears to undertake a new, enhanced role as a means of economic development of European cities. ${ }^{4}$ This can be a twofold argument.

First, the development prospects of European cities are often regarded as associated with certain parameters that are presented (CEC, 1992; Jensen-Butler, 1997; Simioforidis, 1998; Petrakos \& Economou, 1999) as key factors to success: (1) a diverse economic base and qualified human capital; (2) services with high technology and strong local linkages to knowledge-based institutions; (3) developed and modernized infrastructures (transport links and telecommunications, etc.); (4) a high quality of urban environment-built environment, public open space and urban life; and (5) the institutional capacity to develop and implement future-oriented development strategies.

One of the above key factors affecting the competitiveness of a city for new investments and resources within the global urban system of Europe appears to be the quality of urban space. Therefore, in the era of globalization, the relationship between urban economy and urban design, as established throughout the history of urban forms, seems to be being reversed. While for centuries the quality of the urban environment has been an outcome of economic growth of cities, nowadays the quality of urban space has become a prerequisite for the economic development of cities; and urban design has undertaken an enhanced new role as a means of economic development.

Secondly, as Kantor (1987) states, cities in the post-industrial era have become 'captives' of a highly competitive economic environment in which traditional 
factors (e.g. geography and physical infrastructure) that once affected the location of new business in a specific place matter less than ever. Due to the capacity of capital to switch locations, all cities-with the exception of 'global cities' (Sassen, 2001) with sufficient power to mastermind the volatility of capital-have become interchangeable entities to be played off one against one another and forced to compete from positions of comparative weakness for the capital investment (Kantor, 1987). In this process, as Boyle \& Rogerson (2001) argue, the task of urban governance has increasingly become the creation of urban conditions sufficiently attractive to lure prospective firms; and this has entailed what Cox (1993) termed new urban politics. In order to secure development and growth, 'localities' or individual cities now have to offer even more inducements to capital, whether a refashioning of the city's economic attractiveness (e.g. tax abatements, property and transport facilities) or alterations to the city's image through manipulation of its physical form and/or its soft infrastructure (e.g. cultural and leisure amenities) (Boyle \& Rogerson, 2001). This has generated the 'new urban economies', 5 among which cultural and leisure economies are the most widespread and perhaps the most visible manifestations of economic novelty in cities (McNeill \& While, 2001). "Urban regeneration has become a growth industry in itself as a variety of options have opened to urban leaders seeking to rebuild their cities... Derelict industrial sites have been turned into heritage parks, old canals or waterfronts have become housing or restaurant areas, and warehouse conversions have helped build up urban living into something chic" (McNeill \& While, 2001, p. 298). However, the appearance of such development or redevelopment schemes in virtually every city finally puts into doubt the competitive edge that can be gained by such strategies (McNeill \& While, 2001). But if such planning strategies may end up in a zero-sum competition among cities, it seems that design can make the difference.

Due to the growing volatility of capital and the increasing competition among cities, long-term planning can be at odds with the flexibility and the mobility which capital demands (Boyle \& Rogerson, 2001). Harvey (1989a) goes as far as to argue that in the post-modern condition, there is no 'planning', only 'designing'. To play right with volatility of capital by means of 'design', Harvey suggests that there are two options: (1) being highly adaptable and fast-moving in response to market shifts; or (2) masterminding market shifts. The intention underlying the former option is to make short-term gains by responding in every phase to the market needs. The intention underlying the latter option is to make long-term gains by manipulating the market tastes, opinions and needs and making them fit into the proposed design scheme (Boyle \& Rogerson, 2001). This involves the generation of symbols and images (Zukin, 1996a).

\section{Classes and Groups of European Cities, Their Development Prospects and Fitted New 'Uses' of Urban Design}

Building on Harvey's argument, it can be argued that on a general level, the development path of metropolitan cities and larger cities in the core of Europe ('old core $^{\prime 6}$ and 'expanded new core ${ }^{7}$ ) can simultaneously follow both of Harvey's options in relation to design because they acquire sufficient power, mechanisms and human capital to either rapidly shift the design trends and practices so as to constantly meet the changing market needs, or have a normative attitude on the markets tastes, opinions and needs through innovative 
design. In contrast to this, cities in the 'periphery's-economic and/or geographical-and especially smaller cities in the periphery, lacking the necessary power, mechanisms and human capital to quickly respond to the market shifts, appear to have only the latter option, i.e. the production of innovations in design that might generate new trends in the market and, thereby, peripheral cities as pioneers, to secure their development and growth.

To elaborate this argument for all different classes and groups of European cities, the potential and the new 'uses' of urban design should be investigated in relation to the individual economic, social and spatial characteristics of each class and/or group of cities and its development prospects in the European global urban system. In this framework, in order to distinguish the different classes and/or groups of European cities, the present study adopts the classification proposed in formal studies by the CEC (see, for instance, CEC, 1992). In these studies, European cities are classified into three major classesmetropolitan cities, larger cities and smaller cities-with respect to their population. Within some classes, different groups of cities are distinguished with respect to their location (geographical and/or economic): larger cities in the old core or the expanded new core; larger cities in the periphery; smaller cities in the core or the expanded new core; smaller cities in the periphery; smaller cities with special characteristics; and smaller cities without indigenous resources for development.

\section{Metropolitan Cities}

Following the era of decentralization and the flourishing of smaller cities, the late 1980s and the 1990s saw a demographic and economic renaissance of metropolitan cities. This trend towards reurbanization within the metropolitan centres and their suburbs was mainly supported by the reconcentration of certain economic sectors and activities: high-order business services; international distribution; and cultural industries. The metropolitan cities have been retaining their predominance by constantly attracting corporate headquarters, international finance houses, producer services, research and development, high-level public administration, internationally dominant institutions and arts and media industries (see CEC, 1992; Hall, 1996; Petrakos \& Economou, 1999).

On the grounds that the development prospects of European metropolitan cities appear to be mainly associated with the attraction of top-level services, the new uses of urban design fitting into this pattern of development involve the production of a prestigious and symbolic urban landscape, i.e. buildings and open spaces which by means of design and morphology may work as landmarks-symbols and images-reinforcing the spatial identity of the city and thereby attracting top-level activities of the service sector. The production of a prestigious and symbolic urban landscape can be operated by both design paths suggested by Harvey: rapidly adapting design trends that seem to reflect market needs; or introducing design innovations to mastermind market tastes and needs.

During the late 1980s and the 1990s, European metropolitan cities tested such uses of urban design. To exemplify this, London, Paris and Berlin can be used as best cases for the following reasons. First, studies investigating the hierarchy of metropolitan cities of Europe with respect to different criteria, such as urban characteristics (Reclus/Datar, 1989), the ability to attract high-technology econ- 
omic activities (Conti \& Spriano, 1990) and the ability to function as decision centres (Palomaki, 1991) form a consensus in that London and Paris are top in the hierarchy (see Sachar, 1996; Grasland \& Jensen-Butler, 1997). Secondly, from the point of view of urban design, development and redevelopment, Berlin is unique among European metropolitan cities in that it has been the largest construction site during the last decade or so.

In London, efforts to enhance the metropolitan status of the city by means of urban design and the production of a symbolic and prestigious urban landscape were focused on the Docklands redevelopment-the great vision of expanding the City eastwards and doubling the size of London's central business area. Irrespective of any criticism questioning the success of Docklands in economic and/or social terms, recent publications (see Hinsley \& Malone, 1996) consider redevelopment in Docklands as a market-led process which limited the participation of local authorities while permitting exploitation by private interests, and mainly as a form-based framework which marginalized urban planning while offering a great role to architectural and urban design; the Canary Wharf scheme is seen as an example showing this in the best way (Hinsley \& Malone, 1996).

In Paris, under Mitterrand's presidency, it can be said that an innovative design approach was adopted in order to upgrade the city's prestige as a metropolitan centre of Europe. There has been a great investment of public funds in the 'grand travaux' of this period; ${ }^{9}$ these large public projects (public buildings and open spaces), allocated all over Paris, were indeed based on avant-garde design of space that was an outcome of international architectural and urban design competitions (Secchi, 1998).

In Berlin, also, the promotion of the city as a metropolitan centre of Europe has been to a great extent based on innovative architecture and urban design combined with large-scale interventions. ${ }^{10}$ Especially after the demolition of the wall in 1989, the nomination of Berlin as the capital of Germany was followed by a large number of international urban design competitions concerning the redevelopment of Berlin's declining areas close to the wall: Potzdamerplatz, Leipzigerplatz, Friedrichstrasse and Alexanderplatz (Kapitzki, 1996). Design innovations were used as the main driving force for the transformation of declining areas into new prestigious entrepreneurial centres.

\section{Larger Cities}

Following the 1950s and 1960s, which marked an era of extensive urbanization, concentration of the economy and the growth of European larger cities, ${ }^{11}$ the 1970s and 1980s saw a deterioration of urban environment and life in larger cities: congestion, environmental pollution, social conflicts and loss of identity and sense of community, etc. These spatial disadvantages along with certain diseconomies of larger cities (e.g. lack of space, expensive land, expensive overheads and services and obsolescent infrastructure) made this class of cities less attractive as an entrepreneurial or residential location. For larger cities in the periphery, the deterioration of the urban environment was even worse, since they had experienced rapid and unregulated economic and physical growth due to extensive rural immigration (CEC, 1992).

Making European larger cities attractive again as entrepreneurial and residential locations and improving their competitiveness in the European global urban system necessarily means upgrading the quality of their built environment. 
Therefore, uses of urban design fitting into their development prospects involve redevelopment, renewal, reconstruction and revitalization of urban space. In recent decades, larger cities have focused on such themes of urban design in their efforts to regenerate the local economy, more precisely as follows.

- Larger cities in economic decay, such as port cities in decline and old industrial cities, have often considered redevelopment, renewal, reconstruction and revitalization of historic centres, or declining urban areas or waterfronts, etc., as a top priority in the hierarchy of their actions to restructure the local economy. As such cases, one could mention Liverpool and the redevelopment of the city's docks in the 1980s as well as Rotterdam and the redevelopment of the waterfront area of Kop van Zuid in the 1990s. In both cases, redesigning of urban space was focused on adding to the architectural heritage and producing at the same time new space for flourishing economic activities and lively uses (leisure, culture, commerce, offices and housing), so as to help the restructuring of the local economy (van der Knaap \& Pinder, 1992; Craig-Smith, 1995).

- Larger cities, whether located in the core or the periphery of Europe, have been making great efforts to accommodate major international events, such as the Olympic Games and international exhibitions, etc., in the last decade. This has been because events of this kind are considered catalysts to make major improvements in the physical landscape and the architecture of the city; in other words, to launch programmes and realize projects which after the event would have a permanent effect on the city and its life and would add to the development prospects. As such cases, one could mention Barcelona in the new core and Seville and Thessaloniki in the periphery.

The Olympic Games of 1992 hosted in Barcelona served as a catalyst to accelerate the city's physical, economic and social restructuring during the period 1986-92. The strategic plan of the city (1988), ${ }^{12}$ aiming to transform Barcelona into an international entrepreneurial and tourist city, was focused on the enhancement of the city's image by means of avant-garde architectural and urban design schemes distributed all over the city (the historic centre, residential areas and waterfronts) (CEC, 1992; Trullen, 1996; Busquets, 1998).

Seville capitalized upon the accommodation of the World's Fair Expo 1992 for both modernizing the city's physical and telecommunications infrastructure and regenerating a large neglected urban area. Seville has set a significant example of strategic exploitation of a prestige redevelopment project. A formerly neglected urban area was redesigned so as to host the World's Fair Expo 1992 while, after the fair ended, a major science and technology centre was founded on the Expo site, aiming to strengthen sectors already established in Seville (agriculture, food, fisheries and tourism) and encourage new sectors (the aerospace industry, telecommunications equipment, micro-electronics and computers) (CEC, 1992).

Thessaloniki also attempted to maximize the benefits of being the Cultural Capital of Europe in 1997. A self administrated authority, namely the Organization of Cultural Capital of Europe: Thessaloniki '97 (OCCE), was set up to develop and implement a strategic plan for the city. The main objective of the plan, as introduced in 1994, was to improve the city's physical infrastructure, cultural infrastructure and mainly the quality of public open space in order to transform Thessaloniki into a metropolitan centre of the Balkans. In this 
context, a large number of architectural and urban design competitionsnational and international-were carried out concerning a variety of themes (see OCCE, 1998). ${ }^{13}$

\section{Smaller Cities}

Smaller cities flourished in the late 1970s and 1980s-a period which, as previously mentioned, was marked by counter-urbanization in Europe. ${ }^{14}$ Smaller cities were the major beneficiaries of this phenomenon and exhibited rapid growth due to a series of factors (see CEC, 1992).

- The diseconomies associated with larger cities, such as congestion, lack of space, high development costs, expensive overheads and services and obsolescent infrastructure, which prompted decentralization of certain economic sectors (e.g. manufacturing industry) from metropolitan cities and larger cities towards smaller cities.

- Improvements in transports, telecommunications and computer technology, which widened location choices for both business and residents. More specifically, these developments helped smaller cities in two ways. On the one hand, they released business from ties to markets and sources of raw materials and permitted corporate realization into smaller units of production and functional specialization at different sites. On the other hand, they enabled inhabitants of smaller cities to have easier access, both physical and/or electronic, to high-order services and cultural facilities monopolized by metropolitan centres and larger cities.

- High qualities of urban space and life with which smaller cities are endued in comparison with larger cities. As such qualities, one may note urban areas with relatively low people densities, low-rise housing schemes, a higher degree of preservation of traditional architectural and urban forms, lower development costs, closer interfaces between built and natural environment, walking distances among the city's neighbourhoods, less traffic congestion, less environmental pollution, fewer social conflicts and a greater sense of community and identity.

Since the quality of urban space has already been pointed out as a key factor in the growth of smaller European cities during recent decades, new uses of urban design fitting into the development prospects of this class of cities involve the maintenance and enhancement of the quality of urban space. The development prospects of smaller cities are in general assessed (see CEC, 1992) to be favourable; smaller cities are considered to be the dynamic force of modern urban Europe and the majority of them are expected to continue growing successfully in the new competitive milieu. However, the development prospects of distinct groups of smaller cities are considered (see CEC, 1992; Petrakos \& Economou, 1999 ) to vary according to their particular geo-economic characteristics.

- Smaller cities located in the old core or in the expanded new core of Europe are expected to become successfully integrated into the European global urban system mainly in virtue of their location: short distances from metropolitan centres and larger cities; and a well-developed and reliable network of transport links and telecommunications. In particular, those cities located 
along inter-metropolitan corridors of movement and transport are considered as having particularly favourable development prospects associated with their popularity as residential places as well as places for modern distribution, new technology industries and retail firms that prefer less congested but efficient road infrastructure (CEC, 1992; Petrakos \& Economou, 1999). New uses of urban design fitting into the development prospects of this group of smaller cities involve the maintenance of the quality of urban space and its protection against deterioration and possible 'dangers' brought by rapid development, so these cities can constantly attract new investments and new residents.

- Smaller cities with special characteristics, such as resort cities and tourist cities endued with a particularly attractive natural environment, or valuable archaeological and cultural heritage, and university cities and administrative cities with high-order educational and research institutions and international political and administrative institutions, are expected to continue growing successfully into the European global urban system. Their future is mainly associated with the development of tourism, education, research and political and administrative organizations (CEC, 1992; Petrakos \& Economou, 1999). In this group of smaller cities, the quality of urban environment (built fabric and public open space) represents the dominant 'selling product' addressed to both visitors and inhabitants. In this respect, new uses of urban design fitting into the development prospects of this group of cities involve the application of new design trends in the protection and enhancement of the city's architectural heritage and morphology of public open space, so such cities can maintain their status as special cities in the European global urban system.

- The majority of smaller cities located in the periphery (economic and/or geographical) of Europe are expected (see CEC, 1992; Petrakos \& Economou, 1999) to face particular constraints in becoming integrated into the European global urban system. In contrast to smaller cities located in the old or the expanded new core, those located in the periphery usually suffer from major structural weaknesses: inadequate infrastructure (physical infrastructure and telecommunications); limited inward investment; and dependence upon indigenous small firms which are technologically underdeveloped. Although some problems of peripherality may be partially offset by the creation of networks of cities within the global urban system that disseminate best policies and good practice in various sectors and activities and provide technical resources, smaller cities located in remote rural areas and/or which rely upon declining economic activities (e.g. non-competitive agriculture, obsolescent industry and old port activities) are likely to be hit hardest by the increasing intensity of competition within the global urban system. Recourses to counter decline and depopulation are not always available. Some of the cities lack indigenous resources (e.g. valuable archaeological and cultural heritage or a particularly attractive natural environment) to restructure the local economy towards tourism and services; others lack infrastructure and /or qualified human capital to support the development of new, flourishing economic activities such as new-technology industry, services, education functions, arts, crafts and cultural industry (CEC, 1992; Petrakos \& Economou, 1999).

In this group of-relatively disadvantaged-smaller cities, urban design may become a determinant factor for their future; it may become a helpful tool 
serving in the direction of addressing peripherality and decline and restructuring the local economy. Bilbao in Spain has set a significant example. Bilbao's economy, mainly based on traditional industrial units, was in decline during the 1980s. Bilbao's local authorities, following other European cities with similar problems, Glasgow for instance, attempted to regenerate the city's economy via image reconstruction, arts and culture (Gomez, 1998, p. 113) and, more specifically, via the redevelopment of the underused industrial area along the riverside in the centre of the city. The whole area was redesigned according to Cesar Pelli's master plan and transformed into a cultural and leisure district that accommodates the Guggenheim Museum, the Euskalduna Conference Centre and the Performing Arts Palace together with a shopping centre. Large-scale interventions combined with avant-garde design of buildings and open spaces, carried out by internationally acclaimed leading architects (see van Bruggen, 1999), ${ }^{15}$ have transformed Bilbao into an international tourist place. This is clearly shown by the first results concerning the increase of tourists. According to data drawn from the Basque Government's Statistical Authority, the comparison between a time period before the opening of the Guggenheim Museum (January 1994-September 1997) and a time period after the opening of the Guggenheim Museum (October 1997-July 1999) shows that the percentage of foreign travellers has increased by a significant $44.6 \%$, and the percentage of overnight stays has also increased, by a significant 30.8\% (Krens, 1999; Plaza, 1999; 2000a, b).

In particular, the building of the Guggenheim Museum does reinforce a new international paradigm gradually emerging in the last decade and concerning the relationship among urban design, urban space morphology and urban tourism (see Gospodini, 2001a). Irrespective of the particular functions and activities accommodated in space, it is avant-garde design of both buildings and open spaces that can make urban space morphology in itself and of itself a sightseeing, a tourist, attraction. Using the words of Beatriz Plaza, "the avantgarde image of this monumental cubist sculpture of a ship is having a significant positive impact on Bilbao due to the museum's capacity for attracting tourists and for improving Bilbao's image. From the opening of the Guggenheim-Bilbao Museum, the city is exercising a great leap forward" (Plaza, 1999, p. 592).

Although the dramatic increase of tourism in Bilbao, as presented above, allows us to be optimistic about the future regeneration and restructure of the local economy towards services, one should also mention critical attitudes on Bilbao's urban redevelopment. From the architectural point of view, some scholars (see, for instance, Battaglia, 1998) appear to be critical towards the adopted internationalized design trends that are in great contrast to local architectural and urban space morphology. Others, from the socio-economic point of view (see, for instance, Gomez, 1998), are questioning the ability of the tourism increase to regenerate the local economy in terms of the city's unemployment rates and income per capital.

Figure 1 summarizes the arguments of the present study and presents new uses of urban design fitting into the development prospects of different classes and groups of cities within the European global urban system.

\section{Conclusions: European Cities Internationalizing Their Landscape to Meet Economic Globalization: Towards a New Concept of 'Locale'}

As shown in Figure 1, urban design has a significant positive impact on the 


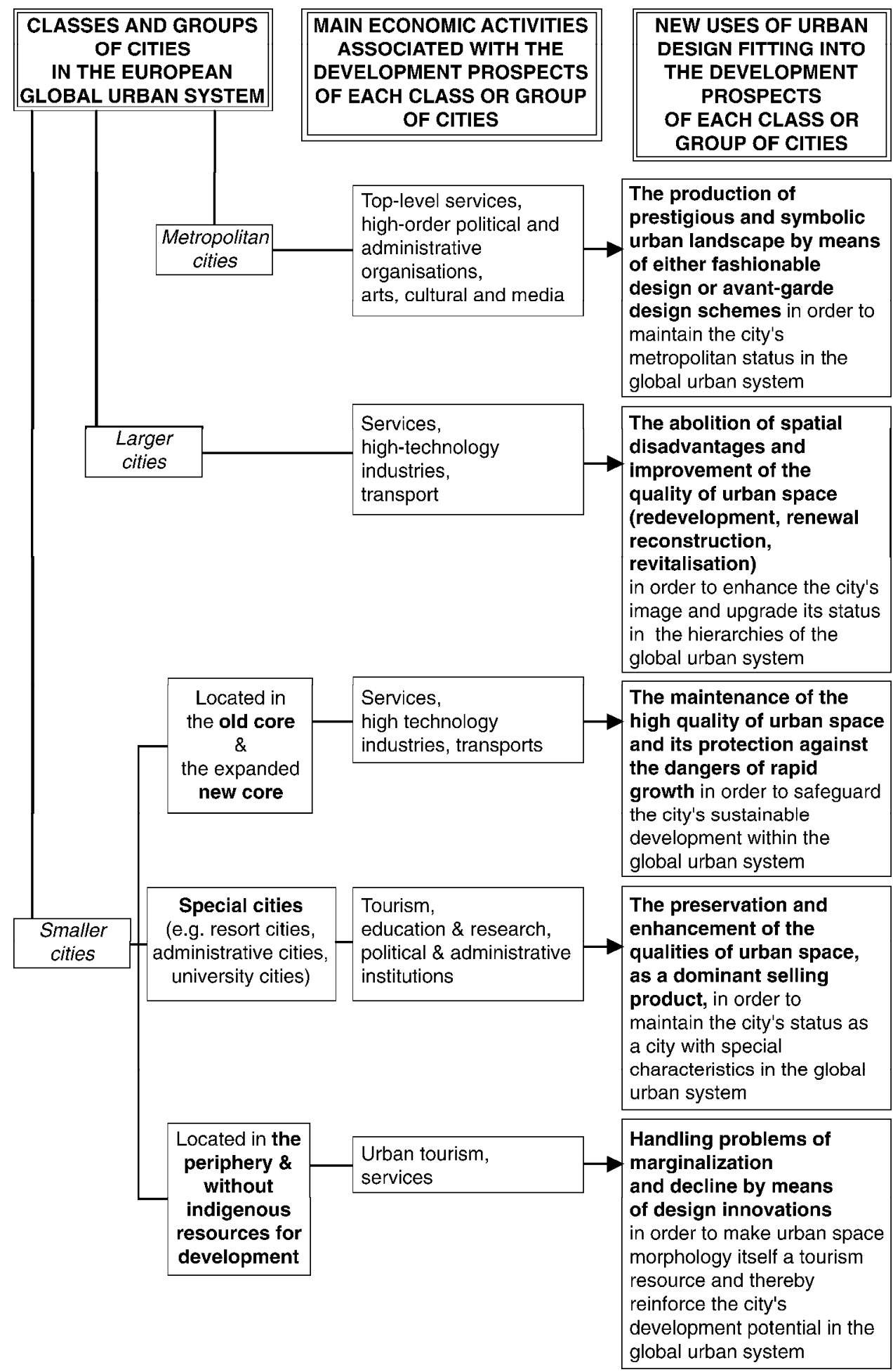

Figure 1. Classes and groups of European cities, their development prospects in the European global urban system and fitted new uses of urban design. 
economic development of all classes and groups of cities within the European global urban system. However, it becomes a key factor in the development of two groups of cities representing the opposite extremes of this system: metropolitan cities and smaller peripheral cities without indigenous resources for development. In both cases, avant-garde design of urban space combined with large-scale interventions appears to control the city's future. In the former case, it can support the city's metropolitan status through the production of a prestigious and symbolic urban landscape, while in the latter case it can handle problems of peripherality and decline and place the city on the European urban map as a tourist place through the transformation of urban space morphology itself into a tourism resource.

If it is supposed that in the framework of inter-city competition, new urban politics will be encouraging the production of symbolic and prestigious urban landscape in European metropolitan cities as well as the transformation of urban space morphology of smaller peripheral cities into a tourism resource through innovative design of space, then two issues are raised, which are perhaps important not just for European cities but for all cities. First, how do avant-garde urban design schemes combined with large-scale interventions relate to the 'locale' of cities-place identity and local culture? Secondly, can the result of transforming urban space morphology itself into a tourist attraction through innovative design finally end up in destroying place identity and culture and, in this respect, generating a sort of discrimination between the prosperous cities in the core and the less prosperous cities in the periphery of Europe? ${ }^{16}$

Zukin (1996b), studying the representational aspects of the city, recognizes a bilateral relationship between visual artefacts, including architectural and urban design schemes, and social structure. The social structure of the city is conceptualized in streets and neighbourhoods, types of buildings, individual buildings and even parts of buildings. Visual artefacts of material culture reinforce or commend social structure. By making social rules legible they re-present the city. On this ground, making a place in the city and creating images-by means of urban design, architecture, arts or even media corporations like the Disney Company-go along with establishing a place identity for the city as a whole and creating new space for public culture (Zukin, 1996b).

Stretching Zukin's thesis, it can be argued that avant-garde urban design schemes, often combined with large-scale interventions, are-exactly through their innovative character as juxtaposed with either existing local morphologies of urban space or established local and/or international design trends-able to create strong images and, thereby, establish a strong place identity for the city as a whole and create new space for public culture. The critical question is what place identity and what public culture is encouraged by them.

In the case of metropolitan cities, avant-garde urban design schemes, contradicting established international design trends, representing pioneer artefacts and producing a symbolic and prestigious landscape, go in harmony with the city's heritage as an international centre and the desirable place identity and public culture. According to Zukin (1996b), in global cities the strategy of producing spaces for cultural hegemony imposes a new way of seeing urban landscape-internationalizing it; because it is inherent in the symbolic economy of a global city, to shape the tastes of global elites and aid in the circulation of images that influence 'climates' of opinion and investments and 'mentalities'.

In the case of smaller peripheral cities, avant-garde urban design schemes, 
contradicting local morphology of urban space and/or established local or international design trends and transforming urban space morphology itself into a tourist attraction, establish a new place identity and a new public culture that can be in contradiction with local heritage. Whether such contradictions to local heritage may result in preventing smaller peripheral cities from such a use of urban design or consolidating a new form of localism is difficult to foresee. According to Castells (1993), in the next decades European cities will be increasingly oriented towards their local identity and local culture as a response to an identity crisis rooted in two realities: (1) the march to supra-nationality within the European Union blurs national identities and makes people uncertain about the power holders of their destiny, thus pushing them into withdrawal, either individualistic (neo-liberalism) or collective (neo-nationalism); and (2) the intensified phenomenon of migration-legal or illegal-to European cities is gradually transforming European urban societies from culturally bounded and mostly homogeneous entities into multi-cultural and heterogeneous entitiesprecisely at the moment when national identity is most threatened.

On the opposite line, Harvey (1989b) argues that the production of a new urban image-whether contradicting local heritage or not-can, if successful, counteract the sense of alienation and anomie and shape a new form of localism. It can particularly do so when an urban terrain is opened for display, fashion and the 'presentation of self' in a surrounding of spectacle and play. "If everybody from the punks and rap artists to the yuppies and the haute bourgeoisies can participate in the production of an urban image through the production of social space, then all can at least feel some sense of belonging to that place" (Harvey, 1989b, p. 58). This may create a sense of social solidarity, civic pride and loyalty to place and even allows the urban image to provide a mental refuge in a world that capital treats as more and more placeless.

Harvey's thesis seem to be supported by the case of the Guggenheim Museum in Bilbao, which, although contradicting local urban space morphology, seems to have created a new urban image that generates a sense of belonging to various social groups. As reported (see Plaza, 1999), on the opening day, inhabitants and tourists, families with children, elderly people, nuns, priests and artists were queuing to enter the building. Harvey's point of view is also supported by entrepreneurs who, being motivated by a combination of philanthropy, civic pride and desire to promote economic development in their home cities, attempt to produce (even in developing countries in the periphery of the USA and Europe) what Zukin (1996a) calls symbolic economy of cities; they attempt to stamp on their home cities a new place identity by financing innovative design of space in cultural complexes (exhibition centres, art museums and parks, etc.) which, in terms of urban space morphology, are in great contrast to local heritage, representing a world-class city. Campera Cultural City, ${ }^{17}$ currently being developed in the desert surrounding the city of Guadalajara in Mexico and financed by Horhe Vergara Campera, is typical of such a case.

\section{Notes}

1. The integration process, apart from a common market, a common resident status and a common currency, which have already become a reality, is heading on with a common defence and foreign policy, a common technology and a common environmental policy, etc.

2. Harvey (1989a) describes various strategies by which cities may compete for investment or resources: (1) competition within the spatial division of labour (improving technology and 
infrastructure and cutting labour conditions); (2) competition within the spatial division of consumption (attracting and retaining tourists and high-income residents); (3) competition to become financial, governmental or informational centres; and (4) competition for governmental distribution.

3. The term 'new centrality', often encountered in recent literature on cities in the globalized economy, remains open to interpretations. For instance, Sassen (2001) writes that new technologies and globalization engender a whole new problematic about what constitutes 'centrality' today (1) in an economic system where a share of transactions occur through technologies that neutralize distance and place and (2) since centrality has historically been embodied in certain urban forms-the central business district.

4. The way this new role of urban design can be a challenge for Greek cities in the redevelopment of their waterfronts is presented in Gospodini (2001a).

5. For 'new urban economies', McNeill \& While (2001) present a fourfold typology: agglomeration economies; informational and knowledge-rich economies; technopoles; and urban leisure economies.

6. As introduced in formal studies by the CEC (see CEC, 1992), the term 'old core' refers to the older industrialized areas of Europe: the UK, northern and eastern France, northern Germany, the Netherlands, Luxembourg and Denmark.

7. As introduced in formal studies by the CEC (see CEC, 1992), the term 'expanded new core' refers to southern Germany, northern Italy, south-eastern France and central-eastern Spain.

8. As introduced in formal studies by the CEC (see CEC, 1992), the 'periphery' of the system includes southern Italy, western France, Ireland, Greece, the rest of Spain and Portugal.

9. The great architectural and urban design projects, supported by President Mitterrand, and constructed in Paris in the late 1980s and 1990s, are the following: (1) the Orsay Museum (2) the theme park of La Villette, including major building complexes such as the City of Science and Industry and the City of Music, as well as open spaces dedicated to special activities; (3) the building of the Institute of the Arabic People; (4) the building of the Ministry of Economics; (5) the Arch of La Defense; (6) the opera building at Bastille; (7) the glass pyramids of the Louvre Museum; (8) the building of the National Library; (9) the building complex of the International Convention Centre; and (10) the building of the National History Museum.

10. Already in the 1980s, the Internationale Bauausstellung Berlin (IBA) programme, aiming to rehabilitate derelict residential quarters within the city, gradually launched a series of international design competitions in order to apply all different new trends of design in the reconstruction of urban space (see IBA, 1986, 1987).

11. Larger European cities are considered those cities with a population of more than 500000 inhabitants (Lavergne \& Mollet, 1991).

12. The four goals of the strategic plan were as follows.

- The promotion of the city as the centre of a macro-region by developing and modernizing infrastructure (transport links, road system, airports and telecommunications), and thereby improving accessibility to the city.

- The promotion of the city as a business centre by developing a centre for new technologies directed at medium- and small-sized businesses and aiming to strengthen the industrial and service sectors.

- The enhancement of the city's image as an attractive place to live and work by means of major architectural and urban design schemes aiming to improve and restructure public open space, to develop new leisure open spaces and sporting facilities and to shift the heart of the city towards the waterfront area, formerly underused.

- The promotion of the city as a tourist centre by adding to the cultural infrastructure and the architectural heritage: new cultural amenities; and conservation of historic urban cores, buildings and spaces (see Trullen, 1996; Busquets, 1998).

13. These were as follows.

- The development and modernization of transport links (road system and airport) in order to facilitate accessibility to the city and promote the city as a metropolitan centre of the Balkans.

- The development and modernization of the cultural infrastructure: new theatres, museums and exhibition and music halls, as well as renovation of existing cultural buildings (OCCE, 1998).

- The reinforcement of the historical identity and the architectural heritage of the city (OCCE, 1998): presernvation, conservation and renewal of buildings, open spaces and areas; 'archae- 
ological promenades' integrating archaeological ruins and historical buildings into a continuous system of pedestrianized public open spaces; and small-scale redesign of open space around archaeological ruins and historical monuments.

- The restructuring of public open space by means of major urban design interventions (OCCE, 1998): the renewal of the central harbour pier so as to accommodate cultural activities; the redevelopment of the city's east waterfront area; and the redevelopment of underused army camps for culture and leisure activities.

14. Smaller European cities are considered to be those cities with a population of less than 500000 inhabitants (Lavergne \& Mollet, 1991).

15. Apart from Cesar Pelli, who worked on the master plan, Frank O. Gehry has designed the Guggenheim Museum and Norman Foster has designed the metro stations.

16. Cities of the former Eastern countries of Europe also represent a new periphery in the European global urban system.

17. This cultural city includes an exhibition centre, a university, a museum of architecture and design, theatres, shops and athletic grounds. Aiming for the innovative design of space, H. V. Campera invited 11 famous architects-Daniel Libeskind, Toyo Ito, Zaha Hadid, Philip Johnson, Thorn Mein, Bill Chien, Jean Nouvel, Enrike Norten, Thedoro Gonzales De Leon, Carmen Pinos and Coop Himmelblau-and encouraged them to test their new ideas.

\section{References}

Amin, A. \& Thrift, N. (1995) Globalization, Institutions, and Regional Development (Oxford, Oxford University Press).

Battaglia, R. (1998) Shame in Spain, Architecture, 87 (2), p. 19.

Boyle, M. \& Rogerson, R. J. (2001) Power, discourses and city trajectories, in: R. Paddison (Ed.) Handbook of Urban Studies (London, Sage).

Brotchie, J., Barry, M., Blakely, E., Hall, P. \& Newton, P. (Eds) (1995) Cities in Competition: Productive and Sustainable Cities for the 21st Century (Melbourne, Longman Australia).

Bruggen, C. van (1999) Frank O. Gehry: Guggenheim Museum Bilbao (New York, Guggenheim Museum Publications).

Busquets, J. (1998) Urban strategies on an intermediate scale [English summary of the Italian article 'Barcelona: strategie urbane alla scala intermedia'], in: F. Infussi \& Y. Simioforides (Eds) Programma Heracles: Le Sfide Della Citta Greca (Athens, Linora).

Castells, M. (1989) The Informational City (London, Blackwell).

Castells, M. (1993) European cities, the informational society, and the global economy, Journal of Economic and Social Geography, 84 (4), pp. 247-257.

CEC (1992) Urbanisation and the Function of Cities in the European Community, Regional Development Studies 4 (Brussels, CEC).

Conti, S. \& Spriano, G. (1990) Effeto Cita (Torino, Fondazione Agnelli).

Cox, K. (1993) The local and the global in the new urban politics: a critical review, Environment and Planning C: Society and Space, 11, pp. 433-448.

Cox, K. (1995) Globalization, competition and the politics of local economic development, Urban Studies, 32, 213-224.

Craig-Smith, S. J. (1995) The role of tourism in inner-harbor redevelopment: a multinational perspective, in: S. J. Craig-Smith \& M. Fagence (Eds) Recreation and Tourism as a Catalyst for Urban Waterfront Redevelopment (Westport, CT, Praeger).

Duffy, H. (1995) Competitive Cities: Succeeding in the Global Economy (London, Spon).

Gomez, M. (1998) Reflecting images: the case of urban regeneration in Glasgow and Bilbao, International Journal of Urban and Regional Research, 22, pp. 106-121.

Gospodini, A. A. (2001a) Urban waterfront redevelopment in Greek cities; a framework for redesigning space, Cities, 18 (5), pp. 285-295.

Gospodini, A. A. (2001b) Urban design, urban space morphology, urban tourism; an emerging new paradigm concerning their relationship, European Planning Studies, 9, pp. 925-935.

Grasland, L. \& Jensen-Butler, C. (1997) The set of cities, in: C. Jensen-Butler, A. Shachar \& J. van Weesep (Eds) European Cities in Competition (Aldershot, Ashgate).

Hall, P. (1996) Cities of Tomorrow (London, Blackwell).

Hall, P. (1998) Cities in Civilization (London, Weidenfeld \& Nicolson).

Harvey, D. (1989a) The Postmodern Condition (Oxford, Blackwell).

Harvey, D. (1989b) From managerialism to entrepreneurialism: the transformation in urban governance in late capitalism, Geografiska Annaler, 71B, pp. 3-17, republished in: M. Miles, T. Hall \& I. Borden (Eds) The City Cultures Reader, pp. 50-59 (London, Routledge). 
Hinsley, H. \& Malone, P. (1996) London: planning and design in Docklands, in: P. Malone (Ed.) City, Capital and Water (London, Routledge).

IBA (1986) Beispiele einer neuen Architektur (Berlin, IBA Publications).

IBA (1987) Projektubersicht (Berlin, IBA Publications).

Jensen-Butler, C. (1997) Competition between cities, urban performance and the role of urban policy: a theoretical framework, in: C. Jensen-Butler, A. Shachar \& J. van Weesep (Eds) European Cities in Competition (Aldershot, Ashgate).

Jensen-Butler, C., Shachar, A. \& van Weesep, J. (1997) (Eds) European Cities in Competition (Aldershot, Ashgate).

Kantor, P. (1987) The dependent city: the changing political economy of urban economic development in the United States, Urban Affairs Quarterly, 22, pp. 493-520.

Kapitzki, C. (1996) Berlin-Visionen werden Realitat (Berlin, Jovis).

King, A. D. (1990) Global Cities: Post-imperialism and the Internationalization of London (London, Routledge).

Knaap, G. A. van der \& Pinder, D. (1992) Revitalizing the European waterfront: policy evolution and planning issues, in: B. S. Hoyle \& D. A. Pinder (Eds) European Port Cities in Transition (London, Belhaven Press).

Krens, T. (1999) Conversation with Thomas Krens, director of the GMB in Bilbao, Connaissance des Artes, 559, pp. 106-107.

Lavergne, F. \& Mollet, P. (1991) The international development of intermediate sized cities in Europe: strategies and networks, in: W. Lever \& A. Bailly (Eds) The Spatial Impact of Economic Changes in Europe (Avebury, Aldershot).

McNeill, D. \& While, A. (2001) The new urban economies, in: R. Paddison (Ed.) Handbook of Urban Studies (London, Sage).

OCCE (1998) Thessaloniki 2000: On the Map of the European Metropolitan Cities. A Complete Catalogue of the Works, Projects and Architectural Competitions (Thessaloniki, OCCE Publications).

Palomaki, M. (1991) On the possible future west European capital, Geojournal, 24, pp. 257-267.

Petrakos, G. \& Economou, D. (1999) Internationalisation and structural changes in the European urban system, in: D. Economou \& G. Petrakos (Eds) The Development of Greek Cities (Athens, Gutenberg \& University of Thessaly Publications) (in Greek).

Plaza, B. (1999) The Guggenheim-Bilbao Museum effect: a reply to Maria V. Gomez, 'Reflective images: the case of urban regeneration in Glasgow and Bilbao', International Journal of Urban and Regional Research, 23, pp. 589-593.

Plaza, B. (2000a) Guggenheim Museum's effectiveness to attract tourism, Annals of Tourism Research, 27, pp. 1055-1058.

Plaza, B. (2000b) Evaluating the influence of a large cultural artifact in the attraction of tourism: the Guggenheim Museum Bilbao case, Urban Affairs Review, 36, pp. 264-274.

Reclus/Datar (1989) Les Villes Europeennes (Montpellier, DATAR).

Sachar, A. (1990) The global economy and world cities, in: A. Sachar \& S. Oberg (Eds) The World Economy and the Spatial Organization of Power (Aldershot, Avebury).

Sachar, A. (1996) European world cities, in: W. Lever\& A. Bailly (Eds) The Spatial Impact of Economic Changes in Europe (Avebury, Aldershot).

Sassen, S. (1994) Cities in a World Economy (Thousand Oaks, CA, Pine Forge).

Sassen, S. (2001) Cities in the global economy, in: R. Paddison (Ed.) Handbook of Urban Studies (London, Sage).

Savitch, H. V. (1996) Cities in a global era: a new paradigm for the next millennium, in: M. E. Cohen (Ed.) Preparing for the Urban Future (Washington, DC, Wooddrow Wilson Center Press).

Secchi, B. (1998) The drifts in renovatio urbis in town planning in Europe today [English summary of the Italian article 'Tendenze della renovatio nella progettazione della citta contemporanea in Europe], in: F. Infussi \& Y. Simioforides (Eds) Programma Heracles: Le Sfide Della Citta Greca (Athens, Linora).

Shaw, D. V. (2001) The post-industrial city, in: R. Paddison (Ed.) Handbook of Urban Studies (London, Sage).

Short, J. R. \& Kim, Y. (1999) Globalization and the City (Harlow, Longman).

Simioforides, Y. (1998) The Greek city and the new urban conditions [English summary of the Italian article 'La citta Greca e le nuove condizioni urbane'], in: F. Infussi \& Y. Simioforides (Eds) Programma Heracles: Le Sfide Della Citta Greca (Athens, Linora).

Trullen, J. (1996) Barcelona, the flexible city, in: J. Trullen (Ed.) Contemporary Barcelona, the Catalogue 1856-1999 (Barcelona, Centre de Cultura Contemporània de Barcelona).

Zukin, S. (1996a) The Cultures of Cities (Oxford, Blackwell).

Zukin, S. (1996b) Space and symbols in an age of decline, in: A. King (Ed.) Representing the City: Ethnicity, Capital and Culture in the 21st Century (London, Macmillan). 
Copyright of Journal of Urban Design is the property of Carfax Publishing Company and its content may not be copied or emailed to multiple sites or posted to a listserv without the copyright holder's express written permission. However, users may print, download, or email articles for individual use. 